\title{
Entomopathogenic nematodes as biocontrol agents in New Zealand agriculture: a case study
}

\author{
N.L. BELL, L.T AALDERS and T.C ROHAN \\ AgResearch, Ruakura Research Centre, Private Bag 3123, Hamilton, New Zealand \\ nigel.bell@agresearch.co.nz
}

\begin{abstract}
Entomopathogenic nematodes (EPNs) have been used experimentally to control insects in pastures and in this study we investigated the use of EPNs against clover root weevil. We tested the ability of two EPNs (Steinernema carpocapsae and Heterorhabditis zealandica) to control soil-dwelling stages of clover root weevil in a Waikato pasture over two spring seasons, with Steinernema being used at two rates in the second year. In the first year, Steinernema EPNs produced a significant reduction in weevil numbers, compared to untreated, 3 weeks after application in October but not 5 weeks after application in November. In the second year, the reduction was not significant after 3 weeks but, a further 2 weeks later, weevil numbers were slightly reduced in EPN-treated soil. No measurable effects were noted from application of Heterorhabditis. Lower soil temperatures likely limited the success of Steinernema in the second spring. Timing of EPN application appears important for controlling clover root weevil. The trial site used here had resident populations of both Steinernema and Heterorhabditis.
\end{abstract}

Keywords: Sitona lepidus, Heterorhabditis bacteriophora, larvae, pupae, Galleria, wax moth

\section{Introduction}

Insect-killing or entomopathogenic nematodes (EPNs) of the genera Steinernema and Heterorhabditis invade (usually larval) insects through their cuticle, whereupon they release symbiotic bacteria from their gut into the insect haemocoel which then kills the insect within 1-2 days (Adams \& Nguyen 2002). The nematodes feed on the bacteria, multiply and eventually release large numbers of infective juveniles to attack more insect hosts. There are around 25 Steinernema and nine Heterorhabditis species currently described worldwide (Adams \& Nguyen 2002). EPNs have been described from every continent except Antarctica (Hominick 2002). Most EPNs are sensitive to exposure to UV and desiccation as they are adapted to attack only soil-dwelling stages of insects.

The symbiotic relationship between EPNs and the bacteria they carry relies on the nematodes to vector the bacteria to host insects and the bacteria to kill the host and produce food for nematode development. Without the bacteria the nematodes cannot reproduce in the host as they have no food source, and without the nematodes the bacteria can infect insects to only a limited degree. The advantage for the bacteria is free host location and delivery, which can involve nematodes being attracted towards exudates of damaged plant roots, and therefore probable sites of insect activity (Rasmann et al. 2005).

The use of entomopathogenic nematodes as potential biocontrol agents for insects has been demonstrated many times in New Zealand (eg Jackson et al. 1985; Jackson \& Wouts 1987; Kain et al. 1982), and the number of studies worldwide is very large with 125 publications on EPNs appearing annually from 1990 to 1998 alone (Hominick 2002).

Clover root weevil (Sitona lepidus) is a serious pest of white clover in the North Island of New Zealand (Gerard et al. 2007) which has the potential to spread throughout the rest of the country (Hardwick et al. 2004). Previous lab work with clover root weevil has shown that EPNs have the potential to be effective biological control agents of this pest (Bell et al. 2000). The current study moved this work to the field stage where spring was chosen as the best time to apply these entomopathogenic nematodes. There were two reasons for this: 1) the clover root weevil population at this time of year is large and consists almost exclusively of soil dwelling stages which are the targets of these nematodes; and 2) prevailing climatic conditions suit nematode survival and activity viz. high soil moisture and rising soil temperatures.

\section{Methods}

The EPNs used in these experiments were Steinernema carpocapsae isolated from soil beneath pasture in the Waikato and Heterorhabditis zealandica isolated from soil beneath kahikatea trees, also in the Waikato. Nematodes were reared in larvae of wax moth (Galleria mellonella) on moist filter paper in Parafilm-sealed petri dishes at $15^{\circ} \mathrm{C}$. After $c a .2$ weeks infected wax moth larvae were transferred to White traps (White 1927) at $20^{\circ} \mathrm{C}$, in order to stimulate production of infective stage nematodes. Nematodes were collected from White traps and stored in aqueous suspension at $4^{\circ} \mathrm{C}$ until required (ca. 1 week).

Initial numbers of clover root weevil soil stages were counted from twenty $10 \mathrm{~cm}$ diameter soil cores at 36, 0 and 0 days before Trials 1, 2 and 3 which were set up on 3 October 2001, 12 November 2001 and 1 October 2002 respectively on a farm at Springdale, Waikato (NZMS260 
Table 1 Nematode treatments and rates applied in Trials 1-3.

\begin{tabular}{clc}
\hline Trial & Nematode treatment & Nematode rate/ ha \\
\hline 1 & Control & 0 \\
(Oct 2001) & Steinernema carpocapsae & $0.69 \times 10^{9}$ \\
& Heterorhabditis zealandica & $0.97 \times 10^{9}$ \\
\hline 2 & Control & 0 \\
(Nov 2001) & Steinernema carpocapsae & $0.95 \times 10^{9}$ \\
& Heterorhabditis zealandica & $0.89 \times 10^{9}$ \\
\hline 3 & Control & 0 \\
(Oct 2002) & Steinernema carpocapsae - Low rate & $0.49 \times 10^{9}$ \\
& Steinernema carpocapsae - High rate & $2.08 \times 10^{9}$ \\
\hline
\end{tabular}

T13 368063). Forty randomised blocks, each containing one replicate of each treatment (see Table 1) were set up in soil cores. For Trial 1, $10 \mathrm{~cm}$ diameter cores were taken to $c a$. $10 \mathrm{~cm}$ depth without regard to the vegetation whereas in Trials 2 and 3 cores were taken over white clover using a soil corer. Cores were removed from the soil and the resulting hole lined with a PVC sleeve, the cores were then replaced in the sleeve. A visual estimate of the percentage of the surface of each core covered by white clover and by the total vegetation was recorded for both Trials 2 and 3 . Trial 2 was set up on the opposite side of the same paddock as Trial 1 , some $10 \mathrm{~m}$ separate, with Trial 3 being located in an adjacent paddock $c a .20$ m separate.

For all trials the nematodes were applied in $1 \mathrm{ml}$ of solution to a slot which was made across the centre of each core to $c a .3 \mathrm{~cm}$ depth. Solutions of nematodes were produced in tap water with the untreated control receiving $1 \mathrm{ml}$ of tap water.

The low initial soil moisture level of Trial 1 meant that the cores were watered prior to nematode inoculation to assist in nematode establishment. Watering was not carried out in Trial 2 and soil moistures in Trial 3 were such that watering was unnecessary.

For Trial 1, the cores and their surrounding PVC sleeves were removed from the soil after 21 days (Week 3 ), for Trial 2 they were removed after 35 days (Week 5) and for Trial 3 they were removed 21 (Week 3, 20 cores) and 38 days (Week 5, 20 cores) after application. Sleeves and cores were placed individually in plastic bags and transported back to Ruakura where they were immediately placed in cool storage $\left(c a \cdot 4^{\circ} \mathrm{C}\right)$.

In Trial 1, clover root weevil larvae, pupae and adults were recovered from 35 soil cores per treatment by handcrumbling cores and subsequent flotation in magnesium sulphate. In Trial 2, 10 replicates per treatment were assessed as for Trial 1 except that weevil eggs were also extracted from five of those replicates by wet sieving. In Trial 3, weevil life stages were assessed by handcrumbling 20 cores per treatment for both the 3 and 5 week post-treatment samplings. In all trials any weevils recovered from soil which appeared to be EPN-infected were collected and subsequently dissected to confirm EPN infection. The genus of EPN infecting the weevils was determined by the colour of the insect: creamy white for Steinernema and red for Heterorhabditis.

To check for the persistence of applied EPNs at the trial site, $100 \mathrm{~g}$ of soil from each of five replicates of each treatment was collected at the end of Trial 1 and baited with five larvae of the greater wax moth (Galleria mellonella) in glass jars with a sealed lid at $20^{\circ} \mathrm{C}$. After 1 week Galleria were removed from the soil and scored as alive, dead or killed by nematodes.

To compare the susceptibility of Galleria to EPNs with that of clover root weevil both insects were added to eight untreated soil samples collected from the trial site at the beginning of Trial 3. From each sample, a 100 g subsample was placed into a jar, insects added (five Galleria and 15 mixed stage weevil larvae) and kept in a $15^{\circ} \mathrm{C}$ controlled environment room for 11 days after which insects were recovered and assessed for nematode infection.

Data were analysed by ANOVA after $\log _{10}(n+1)$ transformation. The percentage of white clover and of vegetative cover in each core was used as co-variates in all analyses.

\section{Results and Discussion}

Although the temperature recordings in Table 2 are from Ruakura and not the trial site, they are indicative of the temperature differences between years. Visual assessment of clover cover in the cores appear to be higher in 2002 than 2001 but it should be remembered that in Trial 1 cores were taken randomly whereas in Trials 2 and 3 they were taken over clover so are biased towards greater clover levels.

There was a significant reduction in the weevil population in the S. carpocapsae treatment in Trial 1 but not in Trials 2 or 3 (Table 3 ). H. zealandica did not significantly reduce weevil numbers. The percent clover and vegetative cover co-variates both had a significant $(\mathrm{P}<0.05)$ effect on the difference between treatments in Trial 1 but not in Trials 2 or 3 which reflected the difference in selecting core positions randomly (Trial 1) 
Table 2 Site characteristics for Trials 1 (3/10/01 to 24/10/01), $2(12 / 11 / 01$ to 17/12/01) and 3 (1/10/02 to 8/11/02). Figures in parentheses are the range.

\begin{tabular}{|c|c|c|c|c|c|}
\hline Trial & $\begin{array}{l}\text { Weeks post } \\
\text { treatment }\end{array}$ & $\begin{array}{l}\text { Soil moisture } \\
\text { (0-5 cm depth) }\end{array}$ & $\begin{array}{l}\text { Mean grass } \\
\min .{ }^{1}\left({ }^{\circ} \mathrm{C}\right)\end{array}$ & $\begin{array}{l}\text { Mean } 10 \mathrm{~cm} \\
\text { soil }^{1}\left({ }^{\circ} \mathrm{C}\right)\end{array}$ & $\%$ clover \\
\hline 1 & 0 & 58.8 & - & - & - \\
\hline (2001) & 3 & 74.4 & $7.3(0.1-14.9)$ & $15.2(13.8-17.3)$ & 9.9 \\
\hline \multirow{2}{*}{$\begin{array}{c}2 \\
(2001)\end{array}$} & 0 & 59.1 & - & - & - \\
\hline & 5 & 80.7 & $11.3(2.7-18.1)$ & $18.2(16.2-20.0)$ & 12.6 \\
\hline \multirow{3}{*}{$\begin{array}{c}3 \\
(2002)\end{array}$} & 0 & 79.9 & - & - & 29.7 \\
\hline & 3 & 65.9 & $1.7(-5.4-9.7)$ & $12.7(10.8-14.4)$ & 40.8 \\
\hline & 5 & 77.7 & $5.1(-2.0-9.5)$ & $13.9(12.4-15.4)$ & 24.2 \\
\hline
\end{tabular}

${ }^{1}$ Temperatures as recorded at Ruakura Research Centre, Hamilton.

Table 3 Mean number of live clover root weevil (CRW) post-egg individuals $/ \mathrm{m}^{2}$ and eggs $/ \mathrm{m}^{2}$ (figures in parentheses are $\log _{10}$ transformed data per core adjusted for percent clover and vegetative cover in cores). Note: Week 0 in Trial 1 is 6 weeks prior to trial initiation, all others are at trial initiation.

\begin{tabular}{|c|c|c|c|c|c|c|}
\hline Trial & Week & Nematode treatment & Total CRW & SED $^{1}$ & CRW eggs & SED \\
\hline 1 & $\begin{array}{l}0 \\
3\end{array}$ & $\begin{array}{l}\text { Control } \\
\text { Control } \\
\text { H. zealandica } \\
\text { S. carpocapsae }\end{array}$ & $\begin{array}{ll}980 & (0.85) \\
593 & (0.63) \\
451 & (0.54) \\
342 & (0.46)\end{array}$ & $\begin{array}{l}(0.072) \\
(0.060)\end{array}$ & $\begin{array}{l}- \\
- \\
-\end{array}$ & \\
\hline 2 & $\begin{array}{l}0 \\
5\end{array}$ & $\begin{array}{l}\text { Control } \\
\text { Control } \\
\text { H. zealandica } \\
\text { S. carpocapsae }\end{array}$ & $\begin{array}{l}248(0.35) \\
57(0.15) \\
85(0.10) \\
57(0.11)\end{array}$ & $\begin{array}{l}(0.114) \\
(0.108)\end{array}$ & $\begin{array}{l}- \\
662(0.79) \\
560(0.67) \\
433(0.57)\end{array}$ & $(0.128)$ \\
\hline 3 & $\begin{array}{l}0 \\
3\end{array}$ & $\begin{array}{l}\text { Control } \\
\text { Control } \\
\text { S. carpocapsae - Low } \\
\text { S. carpocapsae - High } \\
\text { Control } \\
\text { S. carpocapsae - Low } \\
\text { S. carpocapsae - High }\end{array}$ & $\begin{array}{ll}828 & (0.81) \\
732 & (0.77) \\
637 & (0.68) \\
598 & (0.69) \\
433 & (0.55) \\
318 & (0.47) \\
293 & (0.47)\end{array}$ & $\begin{array}{l}(0.063) \\
(0.081)\end{array}$ & $\begin{array}{l}- \\
- \\
- \\
-\end{array}$ & \\
\hline
\end{tabular}

${ }^{1}$ Standard error of difference except for week 0 data which is standard error of mean.

or deliberately over clover (Trials 2 and 3). The considerably cooler temperatures experienced in 2002 compared to 2001 (Table 2), and the consequent lower nematode activity, may help explain the reduced control exerted on clover root weevil by the applied nematodes in that year (Table 3). There appeared to be too few weevils in the soil in Trial 2 to be able to detect any effect from applying EPNs (Table 3) with the reduction in clover root weevil numbers in the soil likely due to their development through to adults (which emerge from soil and feed above-ground).

The total weevil numbers significantly $(\mathrm{P}<0.001)$ declined across all treatments from weeks $3\left(637 / \mathrm{m}^{2}\right)$ to $5\left(376 / \mathrm{m}^{2}\right)$ in the Trial 3 and this was probably due to several factors: viz. adult weevil emergence (Hardwick et al. 2004), mortality from resident nematode infection, Beauveria fungal infection (Brownbridge et al. 2006) and other diseases. There was no significant effect of application rate of $S$. carpocapsae in Trial 3.

At Week 3 in Trial 1, EPN-infected clover root weevil cadavers were recovered only from nematode treated cores (15\% of cores, maximum of one infected weevil per core). However, of the five replicates of cores baited with wax moth for each treatment at Week 3 in Trial 1, three replicates yielded nematode-killed wax moth larvae for the control treatment, one for the $H$. zealandica treatment and two for the $S$. carpocapsae treatment. The EPNs found to be killing wax moth in the control cores were later identified as $H$. bacteriophora (by male and female morphology), a different species to that applied. So it appeared there was a resident population of Heterorhabditis nematodes present at the site.

In Trial 3, EPN-killed weevils were recovered from Week 0 samples ( $10 \%$ of cores) and from untreated (5 and $25 \%$ for weeks 3 and 5 respectively), low rate (30 and $35 \%$ ) and high rate treated cores (20 and 35\%). Of the nematode-infected clover root weevil found in cores from the Week 5 sampling of Trial 3, some from the Steinernema-inoculated cores were found to be infected with either Steinernema or Heterorhabitis while some 
Table 4 Percent reduction in clover root weevil (CRW) life stage numbers $/ \mathrm{m}^{2}$ and the total of all post-egg life stages, compared to untreated control. Note: positive values indicate an increase in number/m².

\begin{tabular}{|c|c|c|c|c|c|c|c|}
\hline Trial & Week & Nematode treatment & Eggs & Larvae & Pupae & Adults & Total CRW \\
\hline 1 & 3 & $\begin{array}{l}\text { H. zealandica } \\
\text { S. carpocapsae }\end{array}$ & $-^{1}$ & $\begin{array}{r}6.3 \\
-30.5\end{array}$ & $\begin{array}{l}-54.8 \\
-61.9\end{array}$ & $\begin{array}{l}-36.8 \\
-21.1\end{array}$ & $\begin{array}{l}-15.4 \\
-37.8\end{array}$ \\
\hline 2 & 5 & $\begin{array}{l}\text { H. zealandica } \\
\text { S. carpocapsae }\end{array}$ & $\begin{array}{l}-15.4 \\
-34.6\end{array}$ & $\begin{array}{r}50.0 \\
-25.0\end{array}$ & $\begin{array}{r}\mathrm{nd}^{2} \\
\mathrm{nd}\end{array}$ & - & $\begin{array}{r}50.0 \\
0.0\end{array}$ \\
\hline 3 & $\begin{array}{l}3 \\
5\end{array}$ & $\begin{array}{l}\text { S. carpocapsae - Low } \\
\text { S. carpocapsae - High } \\
\text { S. carpocapsae - Low } \\
\text { S. carpocapsae - High }\end{array}$ & $\begin{array}{l}- \\
- \\
-\end{array}$ & $\begin{array}{l}-16.7 \\
-16.7 \\
-22.7 \\
-11.4\end{array}$ & $\begin{array}{r}25.0 \\
16.7 \\
-14.3 \\
-33.3\end{array}$ & $\begin{array}{r}0.0 \\
-100.0 \\
-20.0 \\
-80.0\end{array}$ & $\begin{array}{r}-7.8 \\
-11.2 \\
-20.0 \\
-26.7\end{array}$ \\
\hline
\end{tabular}

${ }^{1}=$ none in any cores or not assessed, ${ }^{2}=$ not determined due to none in control cores

Table 5 Percent composition of the clover root weevil population in control cores.

\begin{tabular}{ccccrr}
\hline Trial & Week (Date) & Eggs & Larvae & Pupae & Adults \\
\hline 1 & 3 (23 Oct 2001) & - & 61.3 & 25.8 & 12.9 \\
2 & 5 (12 Dec 2001) & 89.7 & 10.3 & 0.0 & 0.0 \\
3 & 3 (22 Oct 2002) & - & 77.6 & 20.7 & 1.7 \\
& 5 (8 Nov 2002) & - & 58.7 & 28.0 & 13.3 \\
\hline
\end{tabular}

from untreated cores were found to be infected with Steinernema. The nematodes from untreated cores were subsequently identified as $S$. carpocapsae (D. Sturhan pers comm.), but it is considered unlikely that these were present as a result of cross-contamination from treated cores so are most likely resident nematodes.

In addition to clover root weevil larvae being infected by EPNs, larvae were also observed infected with fungi, including what appeared to be Beauveria fungi ( $25 \%$ of cores Week 0, Trial 3)

It appears that Galleria may be a less susceptible host than clover root weevil to the EPNs which infect the weevils because at the end of 11 days at $15^{\circ} \mathrm{C}$ all eight soil samples tested from the trial site (Week 0, Trial 3) produced infected weevil larvae but only three produced infected Galleria. This may be because clover root weevils stay in contact with soil for longer periods than do the mobile Galleria larvae so perhaps appear more susceptible as a result. Additionally, this could be a temperature effect with nematodes not being active enough to infect the larger, more mobile Galleria compared to the smaller, often stationary clover root weevil larvae.

There was a trend for Steinernema EPNs to reduce numbers of all life stages of clover root weevil, including teneral adults (Table 4). Infected cadavers of all stages were found from soil cores. The reduced egg numbers in Trial 2 was somewhat surprising as they are not likely to be attacked directly by EPNs so it is unclear why their number should be reduced.

The composition of the clover root weevil population reflected the effect of lower soil temperatures between years with pupal moulting to adults delayed $c a$. 2 weeks in 2002 (Trial 3) compared to 2001 (Trial 1) (Table 5). It may be that some aspect of clover root weevil population composition, such as percentage of the population that are pupae, could be used as a determinant of the ideal timing to apply EPNs to ensure good weevil control.

\section{Conclusions}

It appears that the trial site used in this study had resident populations of both Steinernema and Heterorhabditis nematodes. Despite this, the application of supplementary EPNs can give added control to clover root weevil, provided they are applied when both temperatures and weevil numbers are high enough to support population growth. Both the presence of resident EPNs and the influence of temperature on EPN effectiveness are issues that would need to be addressed before considering using EPNs in agricultural situations.

What effect the level of nematode infection seen in this study has on clover root weevil is of interest not only for late spring and summer populations but also over the longer term as the ability of nematodes to cycle through the weevils may improve the level of control over time. A study by Jackson \& Wouts (1987) found an effect of applying EPNs was evident a year after application demonstrating that applied EPNs can persist in the pasture environment.

\section{ACKNOWLEDGEMENTS}

The authors thank Mr and Mrs O'Grady for the use of their farm for this study. The project was part-funded from Foundation of Research Science and Technology contract C10X0706. 


\section{REFERENCES}

Adams, B.J.; Nguyen, K.B. 2002. Taxonomy and systematics. pp. 115-143. In: Entomopathogenic Nematology. Ed. Gaugler, R. CAB International, Wallingford, UK.

Bell, N.L.; Jackson, T.A.; Nelson, T.L. 2000. The potential of entomopathogenic nematodes as biocontrol agents for clover root weevil (Sitona lepidus). New Zealand Plant Protection 53: 48-53.

Brownbridge, M.; Nelson, T.L.; Hackell, D.L.; Eden, T.M.; Wilson, D.J.; Willoughby, B.E.; Glare, T.R. 2006. Field application of biopolymer-coated Beauveria bassiana F148 for clover root weevil (Sitona lepidus) control in Waikato and Manawatu. New Zealand Plant Protection 59: 304-311.

Gerard, P.J.; Hackell, D.L.; Bell, N.L. 2007. Impact of clover root weevil Sitona lepidus (Coleoptera: Curculionidae) larvae on herbage yield and species composition in a ryegrass-white clover sward. New Zealand Journal of Agricultural Research 50: 381392.

Hardwick, S.; Addison, P.J.; Eerens, J.P.J.; Gerard, P.J.; Willoughby, B.E. 2004. Factors influencing the rate of spread and impact of clover root weevil (Sitona lepidus Gyllenhal) (Coleoptera: Curculionidae) in New Zealand. pp. 147-154. In: Proceedings of the 8 th
Australasian Conference on Grassland Invertebrate Ecology.

Hominick, W.M. 2002. Biogeography. pp. 115-143. In: Entomopathogenic Nematology. Ed. Gaugler, R. CABI International, Wallingford, UK.

Jackson, T.A.; Pearson, J.F.; Barrow, T.H. 1985. Control of the black vine weevil in strawberries with the nematode Steinernema glaseri. Proceedings of the 38th New Zealand Weed and Pest Control Conference: 158161.

Jackson, T.A.; Wouts, W.M. 1987. Delayed action of an entomophagous nematode (Heterorhabditis sp. (V16)) for grass grub control. Proceedings of the 40th New Zealand Weed and Pest Control Conference: 33-35.

Kain, W.M.; Bedding, R.A.; van der Mespel, C.J. 1982. Preliminary evaluations of parasitic nematodes for grass grub (Costelytra zealandica (White)) control in central Hawke's Bay of New Zealand. New Zealand Journal of Experimental Agriculture 10: 447-450.

Rasmann, S.; Kollner, T.G.; Degenhardt, J.; Hiltpold, I.; Toepfer, S.; Kuhlmann, U.; Gershenzon, J.; Turlings, T.C.J. 2005. Recruitment of entomopathogenic nematodes by insect-damaged maize roots. Nature 434 : 732-737.

White, G.F. 1927. A method for obtaining infective nematode larvae from cultures. Science 66: 302-303. 